\title{
Carbohydrate metabolism alterations in Biomphalaria glabrata infected with Schistosoma mansoni and exposed to Euphorbia splendens var. hislopii latex
}

\author{
Clélia Christina Mello-Silva ${ }^{1 /+}$, Mônica Magno Vilar², Maurício Carvalho de Vasconcellos ${ }^{3}$, \\ Jairo Pinheiro ${ }^{4}$, Maria de Lurdes de A Rodrigues ${ }^{4}$
}

\begin{abstract}
${ }^{1}$ Laboratório de Esquistossomose Experimental ${ }^{2}$ Laboratório de Imunoproteção ${ }^{3}$ Laboratório de Avaliação e Promoção da Saúde Ambiental, Instituto Oswaldo Cruz-Fiocruz, Av. Brasil 4365, 21045-900 Rio de Janeiro, RJ, Brasil Programa de Pós-graduação em Ciências Veterinárias, Universidade Federal Rural do Rio de Janeiro, Seropédica, RJ, Brasil
\end{abstract}

This paper evaluates the alterations in the glycogen content of tissues (digestive gland and cephalopedal mass) and glucose in the haemolymph of Biomphalaria glabrata BH strain infected with Schistosoma mansoni BH strain and exposed to the latex of Euphorbia splendens var. hislopii. A reduction in the glycogen deposits was observed in infected snails exposed and not exposed to latex. However, the exposure to latex caused a greater depletion of the glycogen levels in both sites analysed, especially from the third week onward. The utilisation of latex as a molluscicide to control the population of infected $\mathrm{B}$. glabrata selectively is proposed.

Key words: Biomphalaria glabrata - Euphorbia splendens latex - molluscicide - glycogen content selective control - carbohydrate metabolism

Biomphalaria glabrata is the main intermediate host involved in schistosomiasis in Brazil. Studies have shown that physiological stress conditions, such as infection with Schistosoma mansoni, starvation, aestivation and exposure to molluscicides, can alter its carbohydrate metabolism (Schwartz \& Carter 1982, Becker 1983, Bezerra et al. 1999, Alcanfor 2001, Mello-Silva et al. 2006a). These changes can alter the glycogenesis, gluconeogenesis and glycolysis in the snail.

One of most promising Brazilian molluscicides is the crude extract of Euphorbia splendens (Sin. Euphorbia milii), which under laboratory and field conditions meets the recommendations of the WHO for use as a natural molluscicide (Vasconcellos \& Amorim 2003). Mello-Silva et al. (2006a, 2007) studied the influence of sublethal doses of the latex of this plant on the carbohydrate and protein metabolism and reproductive biology of B. glabrata and found strong metabolic changes leading to a reduction in its population and consequently in the transmission of the parasite. In spite of this potential, there are no studies of the influence of this product on the physiology of Biomphalaria infected with S. mansoni.

The present paper examines the action of the latex of E. splendens var. hislopii on the glucose content of the haemolymph and on the carbohydrate (glycogen) deposits of B. glabrata (BH strain) infected with $S$. mansoni (BH strain).

+ Corresponding author: clelia@ioc.fiocruz.br

Received 25 May 2009

Accepted 10 February 2010

\section{MATERIALS AND METHODS}

Obtaining the latex of E. splendens var. hislopii Samples of E. splendens var. hislopii latex were collected in the autumn from plants cultivated in plots near the Biology Department, Fiocruz, in Rio de Janeiro, Brazil. The latex was collected as described by Vasconcellos and Amorim (2003) on the same day the tests were conducted.

Lethal dose experiment - Using the recently collected latex, an aqueous stock solution at a concentration of $100 \mathrm{mg} / \mathrm{L}$ was prepared and, from this, solutions of different concentrations were prepared for use in the bioassays. The lethal $\left(\mathrm{LC}_{90}\right)$ and sublethal $\left(\mathrm{LC}_{50}\right)$ concentrations were determined according to Vasconcellos and Amorim (2003), as recommended by the World Health Organization (1983) and Mott (1987). The $\mathrm{LC}_{50}$ and $\mathrm{LC}_{90}$ values were, respectively, $1.0 \mathrm{mg} / \mathrm{L}$ and 2.3 $\mathrm{mg} / \mathrm{L}$ (Mello-Silva et al. 2006a).

Balloon flasks $(1000 \mathrm{~mL})$ were used and the latex solution was divided into two $500 \mathrm{~mL}$ glass beakers. The groups of B. glabrata (BH lineage), infected and uninfected, respectively, were placed in $\mathrm{LC}_{50}$ solutions and exposed for $24 \mathrm{~h}$ (Vasconcellos \& Amorim 2003) at $21^{\circ} \mathrm{C}$. Two glass beakers received $500 \mathrm{~mL}$ of distilled water without latex as a control group. None of the snails was fed during this period.

After the latex exposure period, the snails were removed from the flasks and rinsed in distilled water to remove the residues. The number of dead specimens was noted.

Raising and infection of B. glabrata in the laboratory Specimens of B. glabrata (Belo Horizonte - BH lineage), kept at the Laboratório de Esquistossomose Experimental/Instituto Oswaldo Cruz (LEE/IOC)-Fiocruz, RJ, Brazil were used. All the specimens of B. glabrata (600) 
used in the experiments had shell diameters between 8-10 mm. Weekly, 100 snails were individually infected with 5-8 S. mansoni miracidia isolated from eggs from Swiss albino mice maintained in the LEE/IOC-Fiocruz, according to the technique described by Souza and Lima (1990). The snails were grouped according to their infection stage (1 day and 1,2, 3 and 4 weeks post exposure). In each period analysed, 100 infected and 20 uninfected snails (control) were used. Sixty infected snails were exposed to the $\mathrm{LC}_{50}$ concentration of latex and 40 were not exposed, to compare the effects of the E. splendens var. hislopii latex on the infected snails. The 20 infected snails not exposed to latex were maintained to observe cercaria shedding for 40 days. In addition, 20 uninfected and unexposed snails were used as controls. The snails were exposed for $24 \mathrm{~h}$ to E. splendens var. hislopii latex and then were washed in dechlorinated water.

Haemolymph extraction and glucose and glycogen determination - After exposure ( $24 \mathrm{~h}$ and once a week until the 4th week), the haemolymph of the snails was extracted by cardiac puncture and transferred to microtubes. The haemolymph obtained was maintained at $-10^{\circ} \mathrm{C}$ until its use for glucose determination $\left(\right.$ Doles $^{\mathbb{R}}$ ) (Pinheiro 2003). The glucose content was expressed as $\mathrm{mg} / \mathrm{dL}$. After that, the snails were dissected and the digestive gland and cephalopedal mass were separated, weighed and frozen for glycogen determination (Sumner 1924, Pinheiro \& Gomes 1994). The glycogen content was expressed as mg of glucose/g of tissue, fresh weight. The haemolymph and tissues were maintained in an ice bath during the collection procedure.

Statistical analysis - The results of the biochemical determinations were evaluated by the ANOVA, with the Tukey-Kramer test for comparison of the means $(\alpha=5 \%)$ and Student $t$ test for unpaired data. The mean values and standard deviations were assessed by first-order polynomial regression analysis to verify the relation between the changes caused and the period of observation $(\alpha=5 \%)$.

\section{RESULTS}

All infected snails not exposed to latex and maintained for 40 days were positive for S. mansoni cercaria.

The glucose content in the haemolymph, glycogen levels in the digestive gland and cephalopedal mass in the different groups (control, infected unexposed and infected exposed to latex) $(\mathrm{p}<0.05)$ are shown in Table. There were significant differences among these groups in all parameters.

The results demonstrated that $B$. glabrata snails infected with $S$. mansoni and exposed to E. splendens var. hislopii latex during the first day are physiologically similar to snails observed in the first week without latex. In B. glabrata infected and exposed during the first week to latex, the increase in glucose content in the haemolymph $(\mathrm{q}=24.605, \mathrm{p}<0.001)$ and glycogen in the cephalopedal mass $(q=67.719, p<0.001)$ demonstrated changes in the gluconeogenesis pathway. The $B$. glabrata infected with $S$. mansoni in the first and second weeks with and without E. splendens latex showed different physiological alterations. Under similar conditions (1st and 2 nd week) without latex ( $q=5.805, p>0.05)$, the glucose content and glycogen levels in the digestive gland $(\mathrm{q}=1.232, \mathrm{p}$ $>0.001$ ) were not significantly different. Therefore, the glycogen in the cephalopedal mass increased in these periods. When B. glabrata infected with $S$. mansoni was exposed to E. splendens latex, there was a significant decrease between glycogen in the digestive gland and the levels of glycogen in the cephalopedal mass. There was a significant difference in the glucose content in

TABLE

Glucose content in the haemolymph and glycogen in the digestive gland and cephalopedal mass tissues in Biomphalaria glabrata in different periods analyzed - snails uninfected and unexposed to Euporbia splendens var. hislopii latex, snails infected by Schistosoma mansoni and unexposed and exposed to E. splendens var. hislopii latex

\begin{tabular}{|c|c|c|c|}
\hline Snails groups & $\begin{array}{l}\text { Glucose content } \\
\begin{array}{c}(\mathrm{mg} / \mathrm{dL}) \\
\mathrm{X} \pm \mathrm{SD}\end{array}\end{array}$ & $\begin{array}{c}\text { Glycogen content in the } \\
\text { digestive gland }{ }^{a} \\
\mathrm{X} \pm \mathrm{SD}\end{array}$ & $\begin{array}{c}\text { Glycogen content in the } \\
\text { cephalopedal mass }{ }^{a} \\
\mathrm{X} \pm \mathrm{SD}\end{array}$ \\
\hline Uninfected and without latex & $28.03 \pm 17.98^{b}$ & $75.57 \pm 17.07^{b}$ & $20.57 \pm 5.15^{b}$ \\
\hline 1st day without latex & $34.28 \pm 1.47^{b}$ & $20.45 \pm 3.40^{c}$ & $3.79 \pm 0.00^{c, e}$ \\
\hline 1st day with latex & $20.78 \pm 2.93^{b, c, f}$ & $21.82 \pm 10.65^{c}$ & $19.32 \pm 2.74^{b, d}$ \\
\hline 1st week without latex & $16.62 \pm 5.88^{c, f}$ & $12.50 \pm 11.25^{d}$ & $19.32 \pm 4.01^{d}$ \\
\hline 1st week with latex & $69.61 \pm 7.35^{d}$ & $1.36 \pm 0.003^{e}$ & $50.91 \pm 0.78^{c}$ \\
\hline 2nd week without latex & $23.89 \pm 10.28^{c, f}$ & $11.04 \pm 3.94^{d}$ & $6.06 \pm 1.99^{e}$ \\
\hline 2nd week with latex & $73.77 \pm 16.16^{d}$ & $8.28 \pm 1.29^{d}$ & $2.84 \pm 1.72^{f}$ \\
\hline 3rd week without latex & $51.95 \pm 5.88^{e}$ & $10.51 \pm 0.98^{d}$ & $4.09 \pm 3.85^{e}$ \\
\hline 3rd week with latex & $46.75 \pm 30.85^{e}$ & $5.96 \pm 0.74^{d}$ & $6.06 \pm 1.00^{e}$ \\
\hline 4th week without latex & $17.66 \pm 4.40^{f}$ & $25.68 \pm 3.75^{f}$ & $8.71 \pm 1.43^{g}$ \\
\hline 4th with latex & $34.28 \pm 10.28^{g}$ & $\mathrm{ND} \pm \mathrm{ND}$ & $10.74 \pm 0.36^{g}$ \\
\hline
\end{tabular}

$a: \mathrm{mg}$ of glucose/g of tissue, wet weight; ND: not determined; $\mathrm{X} \pm \mathrm{SD}=$ mean \pm standard deviation. Different letters indicates means which differ significantly $(\alpha=5 \%)$. 
the haemolymph $(\mathrm{q}=23.161, \mathrm{p}<0.001)$ and glycogen in the cephalopedal mass $(\mathrm{q}=6.903, \mathrm{p}<0.001)$ of infected B. glabrata in the second week with and without latex, but in the third week, with and without latex, there were no significant differences in parameters (glucose in haemolymph, $\mathrm{q}=2.414, \mathrm{p}>0.05$; glycogen in the digestive gland, $\mathrm{q}=3.554, \mathrm{p}>0.05$; glycogen in the cephalopedal mass, $\mathrm{q}=4.223, \mathrm{p}>0.05$ ). After four weeks, the glycogen levels in the digestive gland of $B$. glabrata infected with $S$. mansoni and exposed to E. splendens latex had declined to levels that were impossible to detect. Comparison of both groups, with and without latex exposure, showed that there was a significant difference in glucose content $(\mathrm{q}=$ $7.717, \mathrm{p}<0.001)$ and glycogen levels in the digestive gland $(q=20.060, p<0.001)$. The polynomial regression analysis showed a weak negative relation between the glucose

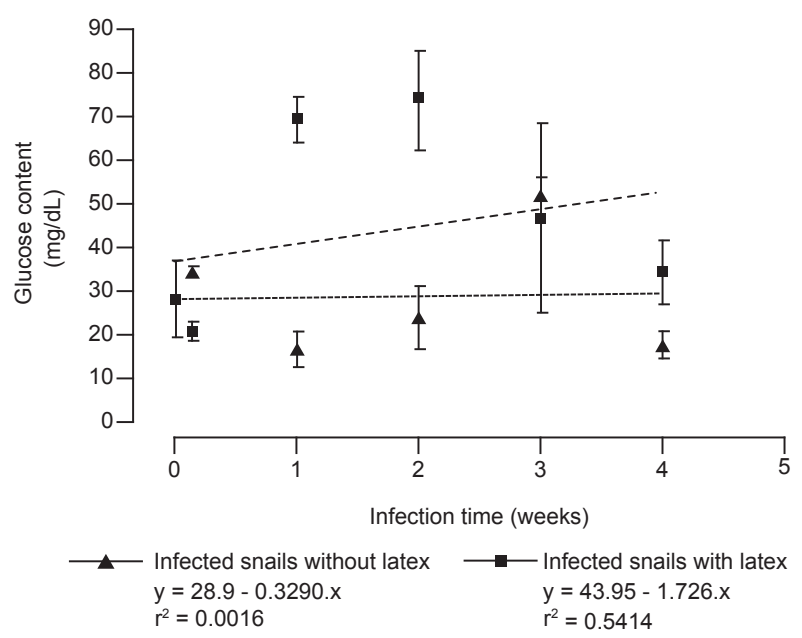

Fig. 1: relation between the glucose content in the haemolymph, as $\mathrm{mg} / \mathrm{dL}$, of Biomphalaria glabrata infected with Schistosoma mansoni and the period after exposure, to $24 \mathrm{~h}$, to Euphorbia splendens var. hislopii latex.

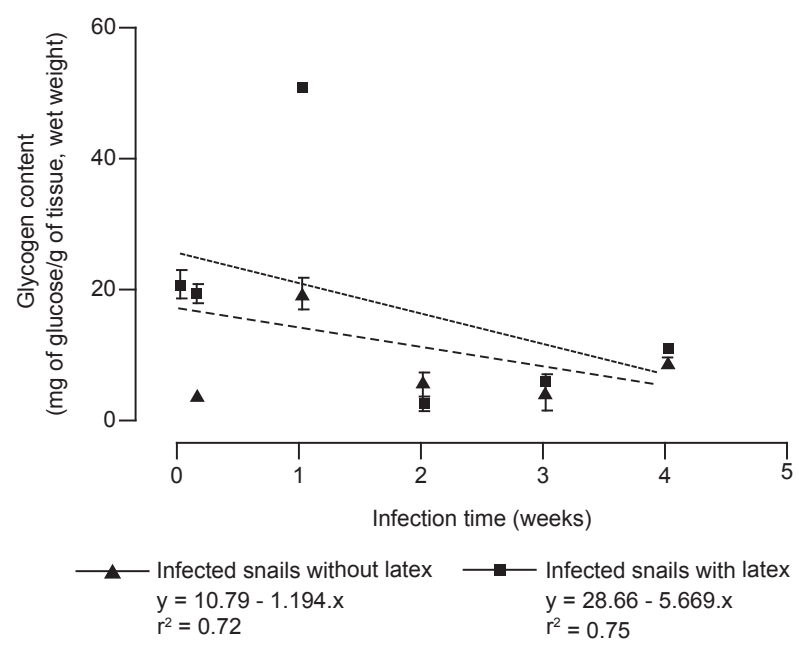

Fig. 2: relation between the glycogen content (mg of glucose/g of tissue, wet weight) in the cephalopedal mass of Biomphalaria glabrata, infected with Schistosoma mansoni, exposed and unexposed to Euphorbia splendens latex and the period after exposure, in weeks. content in the haemolymph (Fig. 1) and the glycogen in the cephalopedal mass (Fig. 2) with the period after exposure in both the infected unexposed and exposed groups. There was also a strong negative relation between the glycogen content in the digestive gland and the period after exposure $\left(r^{2}=0.81\right)$ in both groups (Fig. 3).

\section{DISCUSSION}

Metabolic changes in the glucose and glycogen contents have been observed in trematode-infected snails. The stress caused by the infection can lead to acceleration of gluconeogenesis caused by the increased consumption of glucose from the haemolymph by the larval trematodes. Some authors have shown that the reduction in the content of this monosaccharide in the haemolymph is related to the glycolytic activity associated with gluconeogenesis inhibition (Stanislawsky \& Becker 1979, Becker 1980, Liebsch \& Becker 1990).

The larval intramolluscan development of $S$. mansoni causes an intense drainage of nutrients in the host. These are continuously withdrawn from the haemolymph of the host snail, causing changes in the composition of its haemolymph (Becker 1980, Pinheiro \& Amato 1994). In response to this drainage, the glucose levels in the haemolymph are changed, causing an acceleration of the catalytic activity of the glycogenolysis pathway (Tielens et al. 1992). In this study, the results showed that the energy expenditure caused by the trematode infection and the latex exposure can cause an increase in the ATP consumption and acceleration of glycolysis. This probably slows down the snail's locomotion. When the mother sporocysts change to daughter sporocysts near the digestive gland, glycogen degradation from this organ occurs. The larvae are located in the interfollicular tissue and are bathed by the haemolymph, from which they obtain the glucose needed for the glycogenesis process. They excrete lactate as the final substance of anaerobic metabolism (Bezerra et al. 1999).

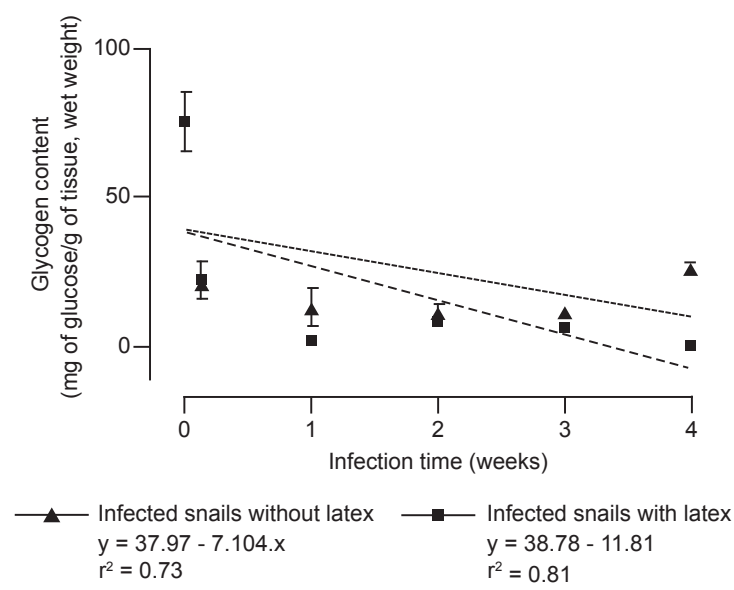

Fig. 3: relation between the glycogen content ( $\mathrm{mg}$ of glucose/g of tissue, wet weight) in the digestive gland of Biomphalaria glabrata, infected with Schistosoma mansoni, exposed and unexposed to Euphorbia splendens latex and the period after exposure, in weeks. 
In the first week of larval development of $S$. manso$n i$, the snails, both those exposed and those not exposed to the latex, showed a reduced glucose level in the haemolymph (hypoglycaemia), causing a reduction in the glycogen content of cephalopedal mass. The low level of glucose in the haemolymph slows glycogenesis and accelerates gluconeogenesis. The hypoglycaemic effect in trematode-infected animals indicates the glycemic regulation also observed in Lymnaea stagnalis and vertebrates (Livingstone \& de Zwaan 1983). The homeostasis of glucose content in the haemolymph of $B$. glabrata was observed by Thompson and Lee (1986).

Changes in the carbohydrate metabolism in snails exposed to molluscicide substances, such as Bayluscide ${ }^{\circledR}$, and natural substances, such as the plant Tetrapleura tetraptera have been reported (Adewunmi et al. 1988). Alcanfor (2001) reported a reduction of the glucose content of the haemolymph of B. glabrata exposed to Stryphnodendron adstringens, Stryphnodendron polyphyllum and Caryocar brasiliense, plants from the Brazilian cerrado (savannah). The consumption of glycogen from the digestive gland and cephalopedal mass was also observed by Mello-Silva (2005) and Mello-Silva et al. (2006a), using sublethal doses of the raw latex of E. splendens var. hislopii. A similar result was obtained by Mello-Silva et al. (2006b) with aqueous extracts of Solanum malacoxylon.

In this study, the variation in glucose content was analysed in snails exposed to a sublethal latex dose for $24 \mathrm{~h}$. It is possible to suppose that the $S$. mansoniinfected $B$. glabrata snails are more susceptible than uninfected snails to the latex of $E$. splendens, showing severe depletion in the carbohydrate deposits and an alteration in glycemia.

This study shows the possibility of using the latex of E. splendens as a natural selective molluscicide in the control of the B. glabrata population infected with $S$. mansoni to control schistosomiasis transmission.

\section{ACKNOWLEDGEMENTS}

To Dr José Clecildo Barreto Bezerra (FAPEG director), for assistance with the experiments.

\section{REFERENCES}

Adewunmi CO, Becker W, Dörfler G 1988. Effect of prolonged administration of sublethal concentrations of aridanin isolated from Tetrapleura tetraptera and bayluscide on the glycogen and protein content of Biomphalaria glabrata. J Ethnopharmacol 24: $107-114$.

Alcanfor JDX 2001. Ação de extratos de plantas do cerrado sobre Biomphalaria glabrata (Say, 1818) hospedeiro intermediário de Schistosoma mansoni (Sambom, 1907), MSc Thesis, Universidade Federal de Goiás, Goiânia, 84 pp.

Becker W 1980. Metabolic interrelationship of parasitic trematodes and mollusks, especially Schistosoma mansoni in Biomphalaria glabrata. Z Parasitenkd 63: 101-111.

Becker W 1983. Purine metabolism in Biomphalaria glabrata under starvation and infection with Schistosoma mansoni. Comp Biochem Physiol B 76: 215-219.

Bezerra JC, Kemper A, Becker W 1999. Profile of organic acid concentrations in the digestive gland and hemolymph of Biomphalaria glabrata under estivation. Mem Inst Oswaldo Cruz 94: 779-784.

Liebsch M, Becker W 1990. Comparative glucose tolerance studies in the freshwater snail Biomphalaria glabrata: influence of star- vation and infection with the trematode Schistosoma mansoni. $J$ Comp Physiol B 160: 41-50.

Livingstone DR, de Zwaan A 1983. Carbohydrate metabolism of gastropods. In PW Hochachka, The mollusca metabolic biochemistry and molecular biomechanics, Academic Press, London, p. 177-242.

Mello-Silva CC 2005. Controle alternativo e alterações fisiológicas em Biomphalaria glabrata (Say, 1818), hospedeiro intermediário de Schistosoma mansoni Sambom, 1907 pela ação do látex de Euphorbia splendens var. hislopii N.E.B (Euphorbiaceae), PhD Thesis, Universidade Federal Rural do Rio de Janeiro, Seropédica, 85 pp.

Mello-Silva CC, Lima MG, Pinheiro J, Bezerra JC, Rodrigues ML 2006a. Alterações fisiológicas em Biomphalaria glabrata tratadas com extrato bruto de Solanum malacoxylon. Ciência Animal 16: 61-70.

Mello-Silva CC, Pinheiro J, Vasconcellos MC, Rodrigues MLA 2006b. Physiological changes in Biomphalaria glabrata Say, 1818 (Pulmonata: Planorbidae) caused by sub-lethal concentrations of the latex of Euphorbia splendens var. hislopii N.E.B. (Euphorbiaceae). Mem Inst Oswaldo Cruz 101: 3-8.

Mello-Silva CC, Vilar MM, Bezerra JC, Vasconcellos MC, Pinheiro J, Rodrigues MLA 2007. Reproductive activity alterations on the Biomphalaria glabrata exposed to Euphorbia splendens var. hislopii latex. Mem Inst Oswaldo Cruz 102: 671-674.

Mott KE 1987. Plant molluscicides, UNDP/World Bank/WHO, John Wiley and Sons, New York, 326 pp.

Pinheiro J 2003. Morfologia e ultraestrutura dos ovos e estágios larvais de Echinostoma paraensei Lie: Basch; 1967 (Trematoda: Echinostomatidae) efisiologia comparada da sua interação com Lymnaea columella Say; 1817 (Mollusca: Gastropoda), PhD thesis, Universidade Federal do Rio de Janeiro, Rio de Janeiro, 183 pp.

Pinheiro J, Amato SB 1994. Eurytrema coelomaticum (Digenea: Dicrocoeliidae): the effect of infection on carbohydrate contents of its intermediate snail host, Bradybaena similaris (Gastropoda, Xanthonychidae). Mem Inst Oswaldo Cruz 89: 407-410.

Pinheiro J, Gomes EM 1994. Method for glycogen determination in mollusc. Arq Bras Biol Tecnol 37: 569-576.

Schwartz CF, Carter CE 1982. Effect of Schistosoma mansoni on glycogen synthase and phosphorylase from Biomphalaria glabrata (mollusca). J Parasitol 68: 236-242.

Souza CP, Lima LC 1990. Moluscos de interesse parasitológico do Brasil, Centro de Pesquisas René Rachou-Fiocruz, Belo Horizonte, $76 \mathrm{pp}$.

Stanislawsky E, Becker W 1979. Influences of semi-synthetic diets, starvation and infection with Schistosoma mansoni (Trematoda) on the metabolism of Biomphalaria glabrata (Gastropoda). Comp Biochem Physiol 63 A: 527-533.

Sumner JB 1924. The estimation of sugar in diabetic urine using dinitrosalicylic acid. J Biol Chem 62: 287-290.

Thompson SN, Lee RW 1986. Comparison of starvation and infection by Schistosoma mansoni on tissue viability and the 31P NMR spectrum of Biomphalaria glabrata. Z Parasitenkd 72: 417-421.

Tielens AG, Horemans AM, Dunnewijk R, van der Meer P, van den Bergh SG 1992. The facultative anaerobic energy metabolism of Schistosoma mansoni sporocysts. Mol Biochem Parasitol 56: 49-57.

Vasconcellos MC, Amorim A 2003. Molluscicidal action of the latex of Euphorbia splendens var. hislopii N.E.B ("Christ's Crown") (Euphorbiaceae) against Lymnaea columella (Say, 1817) (Pulmonata: Lymnaeidae), intermediate host of Fasciola hepatica Linnaeus, 1758 (Trematode: Fasciolidae). 1. Test in laboratory. Mem Inst Oswaldo Cruz 98: 557-563.

WHO - World Health Organization 1983. Report of a scientific Working Group on Plant Molluscicide and Guidelines for Evaluation of Plant Molluscicide, WHO, TDR/SCH-SWE (4)/83.3, Geneve. 